\title{
The endocannabinoid anandamide impairs in vitro decidualization of human cells
}

\author{
M Almada, C Amaral, M Diniz-da-Costa, G Correia-da-Silva, N A Teixeira and B M Fonseca \\ UCIBIO@REQUIMTE, Laboratório de Bioquímica, Departamento Ciências Biológicas, Faculdade de Farmácia da \\ Universidade do Porto, Porto, Portugal \\ Correspondence should be addressed to B M Fonseca; Email: brunofonseca@ff.up.pt
}

\begin{abstract}
Endocannabinoids (eCBs) are endogenous mediators that along with the cannabinoid receptors (CB1 and CB2), a membrane transporter and metabolic enzymes form the endocannabinoid system (ECS). Several eCBs have been discovered with emphasis on anandamide (AEA). They are involved in several biological processes such as energy balance, immune response and reproduction. Decidualization occurs during the secretory phase of human menstrual cycle, which involves proliferation and differentiation of endometrial stromal cells into decidual cells and is crucial for the establishment and progression of pregnancy. In this study, a telomerase-immortalized human endometrial stromal cell line (St-T1b) and non-differentiated primary cultures of human decidual fibroblasts from term placenta were used to characterize the ECS using immunoblotting and qRT-PCR techniques. It was shown that St-T1b cells express CB1, but not CB2, and that both receptors are expressed in HdF cells. Furthermore, the expression of fatty acid amide hydrolase (FAAH), the main degrading enzyme of AEA, increased during stromal cell differentiation. AEA inhibited cell proliferation, through deregulation of cell cycle progression and induced polyploidy. Moreover, through CB1 binding receptor, AEA also impaired cell differentiation. Therefore, AEA is proposed as a modulator of human decidualization. Our findings may provide wider implications, as deregulated levels of AEA, due to Cannabis sativa consumption or altered expression of the metabolic enzymes, may negatively regulate human endometrial stromal cell decidualization with an impact on human (in)fertility.

Free Portuguese abstract: A Portuguese translation of this abstract is freely available at http://www.reproduction-online.org/

content/152/4/351/suppl/DC1.

Reproduction (2016) 152 351-361
\end{abstract}

\section{Introduction}

Human endometrial stromal cells (HESCs) undergo waves of proliferation and differentiation into morphologically and functionally distinct cells called decidual cells. This process, named decidualization, occurs in women during the secretory phase of the menstrual cycle and prepares a receptive uterus for implantation. The decidual process is triggered by sustained activation of the second messenger cyclic adenosine monophosphate (CAMP) and the protein kinase A (PKA) pathway, which in turn sensitizes stromal cells to progesterone (Gellersen \& Brosens 2014). In addition to uterine angiogenesis and homeostasis (Weimar et al. 2013), decidual cells participate in embryo recognition (Norwitz et al. 2001, Teklenburg et al. 2010), regulation of trophoblast invasion and modulation of immune and oxidative stress response at feto-maternal interface (Gellersen \& Brosens 2003). Impaired decidualization, as a result of poor hormone responsiveness and/or impaired endometrial stromal cell growth and/or differentiation, is often associated with implantation failure, unexplained infertility, recurrent spontaneous miscarriage and pregnancy disorders, such as preeclampsia or intrauterine growth retardation and premature birth (Strowitzki et al. 2006).

The endocannabinoids (eCBs), in particular anandamide (AEA) and 2-arachidonoylglycerol (2-AG), the best studied eCBs, are emergent modulators of several pathophysiological processes. Besides the endogenous cannabinoids, the endocannabinoid system (ECS) comprises the cannabinoid receptors (CB1 and (CB2), the enzymes involved in the biosynthesis and degradation of eCBs, and a purported transporter (Fonseca et al. 2013b). AEA is mainly synthesized by $\mathrm{N}$-arachidonoylphosphatidylethanolamine hydrolysing phospholipase D (NAPE-PLD), and, subsequently, hydrolysed to arachidonic acid and ethanolamine by the enzyme fatty acid amide hydrolase (FAAH) (Fonseca et al. 2013b). The latter is considered the major metabolic gatekeeper for AEA uterine levels throughout menstrual cycle and pregnancy (Maccarrone \& Finazzi-Agro 2004, Habayeb et al. 2008). eCBs modulate basic biological processes, 
including the choice between cell proliferation, death and differentiation (Fonseca et al. 2013a). In the rat model, it has been demonstrated that AEA interferes with decidual cell turnover by inducing apoptosis (Fonseca et al. 2013b) and limits uterine stromal cell differentiation (Fonseca et al. 2015). Nevertheless, the underlying mechanisms that govern the process of human endometrial decidualization and the involvement of the eCBs in this process remain poorly understood. Therefore, in this work, we aimed to investigate the role of the main eCB, $\mathrm{AEA}$ on in vitro decidualization process in two cell culture models, an immortalized human endometrial stromal cell line (St-T1b) and human decidual fibroblasts (HdF) derived from human term placenta. The ECS was characterized in non-differentiated and in cells undergoing decidualization, and the role of AEA in these cells was investigated.

\section{Materials and methods \\ St-T1b cell line culture}

The St-T1b was kindly supplied by Dr Birgit Gellersen from Endokrinologikum Hamburg, Hamburg, Germany. This cell line was obtained from uterine biopsy samples at the time of hysterectomy from benign gynaecological disorders and immortalized with human telomerase (hTERT). This cell line displays the typical morphological features of proliferative endometrial fibroblasts and expresses the appropriate lineagespecific markers such as vimentin and CD90 while being CK7-negative (Samalecos et al. 2009). Cells were maintained at $37^{\circ} \mathrm{C}$ with $5 \% \mathrm{CO}_{2}$ in DMEM/F-12 medium (Gibco Invitrogen Corporation, CA, USA) supplemented with $10 \%$ charcoal-stripped foetal bovine serum (CT-FBS) (Gibco Invitrogen Corporation), $1 \mathrm{nM} 17 \beta$-oestradiol $\left(\mathrm{E}_{2}\right)$ (Sigma-Aldrich), $1 \mu \mathrm{g} / \mathrm{mL}$ insulin (Sigma-Aldrich) and $2 \%$ penicillin-streptomycin-amphotericin B (Gibco Invitrogen Corporation). Initially, cells were incubated for $24 \mathrm{~h}$ in complete medium and then experiments were performed in DMEM/F-12 with $2 \%$ CT-FBS.

\section{Primary cultures of $\mathbf{H d F}$}

HdFs isolated from term decidua are undifferentiated fibroblast-like cells of the endometrial stroma (Richards et al. 1995). The protocol for the isolation of fibroblast cells from term decidua was based on Richards et al. (1995). Caesarean or vaginal delivery normal human placentas (38-40 weeks of gestation) from Caucasian women, living in Porto region and aged 24-36years old, were obtained from Centro MaternoInfantil do Norte, Porto. All the procedures using term placentas were performed according to the ethics committee of Centro Materno-Infantil do Norte. The decidua basalis was scraped from the chorionic membrane, dissected into small pieces and enzymatically digested in PBS with collagenase $(1 \mathrm{mg} / \mathrm{mL})$ for $1 \mathrm{~h}$ at $37^{\circ} \mathrm{C}$ with gentle shaking. The suspension was then centrifuged at $260 \mathrm{~g}$ for $6 \mathrm{~min}$. The pellet was resuspended with ammonium chloride $(0.84 \%)$ solution for red blood cell lysis at $37^{\circ} \mathrm{C}$. The resulted suspension was filtered through a $40 \mu \mathrm{M}$ nylon mesh and centrifuged at $260 \mathrm{~g}$ for $10 \mathrm{~min}$. The isolated cells were maintained at $37^{\circ} \mathrm{C}$ with $5 \% \mathrm{CO}_{2}$ in DMEM/F-12 medium supplemented with $10 \%$ CT-FBS, $1 \mathrm{nM} \mathrm{E}_{2}, 1 \mu \mathrm{g} / \mathrm{mL}$ insulin and $2 \%$ penicillinstreptomycin-amphotericin B. After $24 \mathrm{~h}$, the non-adherent cells were discarded and the adherent cells were grown to confluence and sub-cultured. The purity of primary $\mathrm{HdF}$ was confirmed by immunocytochemical analysis for the cytoskeletal proteins vimentin and cytokeratin-7, a fibroblast and an epithelial cell marker respectively (Fig. 1).
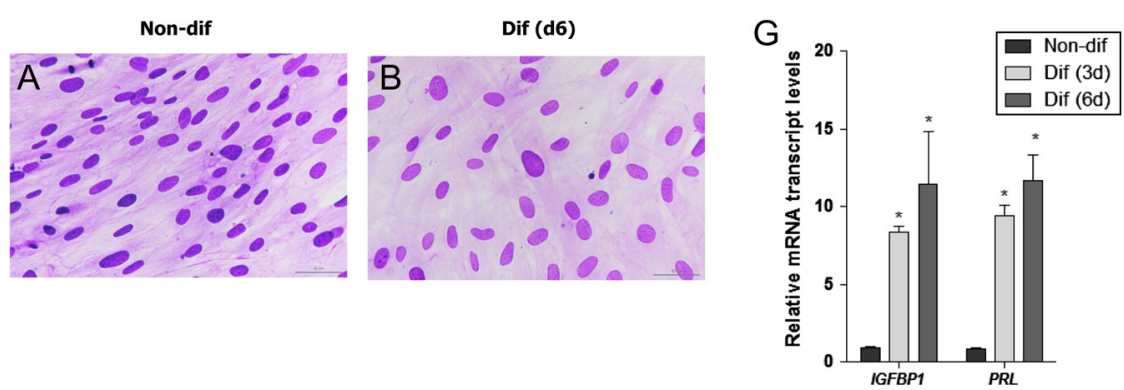
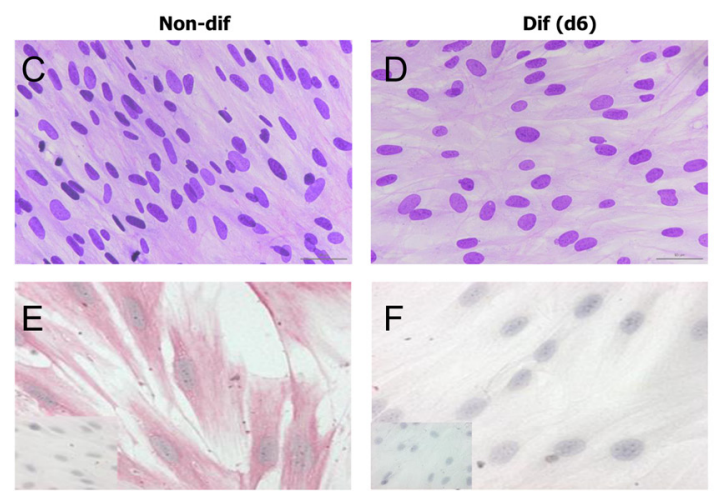

$\mathrm{H}$

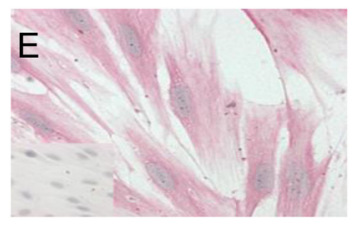

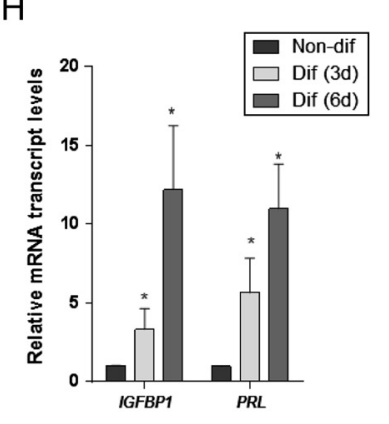

Figure 1 Study of the decidualization process in St-T1 b and HdF cells after 3 and 6 days of exposure to decidualization stimulus. Morphological studies by Giemsa staining of St-T1b cell line, both in non-differentiated (non-dif) (A) and in cells exposed for $6 \mathrm{~d}$ to the differentiation stimulus (dif) (B). Similar to St-T1b cells, in HdF, non-differentiated cells (C) maintain the fibroblastic spindle shape, whereas after 6 days of exposure to decidual treatment, differentiated cells (D) became larger and with rounded nucleus. The purity of primary $\mathrm{HdF}$ was confirmed by immunocytochemical analysis of the expression of the cytoskeletal proteins vimentin $(\mathrm{E})$ and cytokeratin-7 $(\mathrm{F})$ respectively a fibroblast and an epithelial cell marker. Negative control obtained by omitting primary antibody is represented in the square. The steady-state transcript levels of IGFBP1 and PRL were evaluated by qRT-PCR and shown to significantly increase in both St-T1b (G) and HdF cells $(\mathrm{H})$, after 3 and 6 days of decidualization treatment. $\left({ }^{*} P<0.05\right.$ vs Non-dif) $(n=3$; two-way ANOVA, Tukey's multiple comparisons). 


\section{Differentiation treatment}

In vitro differentiation was induced in minimal medium MM1 (DMEM/F-12 medium supplemented with 2\% CT-FBS and $2 \%$ penicillin-streptomycin-amphotericin B) containing $1 \mu \mathrm{M}$ medroxyprogesterone acetate (MPA; Sigma-Aldrich, MO, USA), 10nM E2 and with $0.5 \mathrm{mM}$ 8-bromoadenosine 3', 5'-cAMP (Sigma-Aldrich) or $0.05 \mathrm{mM}$ cAMP, for St-T1b and $\mathrm{HdF}$ respectively. The differentiation process was induced for 3 or 6 days (d), and the medium was changed every $3 \mathrm{~d}$. Cell differentiation was confirmed by morphological analysis and mRNA levels of prolactin (PRL) and the insulin-like growth factor binding protein-1 (IGFBP1), the main secretory products of decidual cells, were evaluated by qRT-PCR. In order to investigate the role of AEA during the decidualization process, cells were treated with the differentiation medium (MM1 + CAMP, $E_{2}$ and MPA) in the presence or absence of AEA $(10 \mu \mathrm{M})$ (Tocris Bioscience, Minneapolis, MN, USA). To explore the role of cannabinoid receptors, cells were pre-incubated with AM281, selective CB1 receptor antagonist/inverse agonist $(1 \mu \mathrm{M}$; Tocris Bioscience) and AM630, CB2 antagonist/inverse agonist ( $1 \mu \mathrm{M}$; Tocris Bioscience) for $30 \mathrm{~min}$ before the addition of AEA $(10 \mu \mathrm{M})$. At this concentration, the antagonists per se did not affect neither the decidual response nor the cell viability. Nondifferentiated cells treated with MM1 were used as a control. Cells from four to ten sub-passages were used in the studies.

\section{Cell viability and rate of DNA synthesis}

$\mathrm{HdF}$ and St-T1b cells were plated at a density of $2.5 \times 10^{3}$ cells/well in 96-well plates and treated with AEA $(10 \mu \mathrm{M})$ in non-differentiated medium (minimal medium, MM1: DMEM/F-12 medium supplemented with 2\% CT-FBS and $2 \%$ penicillin-streptomycin-amphotericin B) and with differentiation medium (MM1+CAMP, $E_{2}$ and MPA). Cell viability was assessed by MTT assay after $6 \mathrm{~d}$ of treatment. The yellow tetrazole MTT $(0.5 \mathrm{mg} / \mathrm{mL}$ final concentration) (Sigma-Aldrich) was added and cells were incubated at $37^{\circ} \mathrm{C}$ for $3 \mathrm{~h}$. The resultant purple formazan was dissolved in a solution of dimethylsulphoxide:isopropanol (3:1) and spectrophotometrically quantified at $540 \mathrm{nM}$. To study the effects of AEA on DNA synthesis, $\left[{ }^{3} \mathrm{H}\right]$-thymidine incorporation assay was performed. In the last $32 \mathrm{~h}$ of each exposure time, $\left[{ }^{3} \mathrm{H}\right]$-thymidine $(0.5 \mu \mathrm{Ci})$ (Amersham) was added to cells. Cells were harvested and, after addition of a scintillation cocktail, $\left[{ }^{3} \mathrm{H}\right]$-thymidine incorporation was determined in a scintillation counter (LS 6500; Beckman Instruments). Results are expressed as relative percentage of the untreated control cells. The results are the mean of at least three independent experiments carried out in triplicate.

\section{Morphological studies}

Morphological alterations induced upon differentiation treatment were evaluated by Giemsa staining. Both cell types were plated at a density of $1.5 \times 10^{4}$ cells/well in 24-well culture plate, and cells were exposed to differentiation treatment for $6 \mathrm{~d}$. After treatment, cells were fixed with $4 \%$ p-formaldehyde in PBS for $20 \mathrm{~min}$ at $4{ }^{\circ} \mathrm{C}$ and stained with Giemsa for $30 \mathrm{~min}$. Cells were observed under the microscope Eclipse E400, Nikon equipped with image analysis software LeicaQwin (Cambridge, UK).

\section{qRT-PCR analysis}

The assessment of steady-state transcript levels was carried out by qRT-PCR. For these studies, cells were seeded at a cellular density of $5 \times 10^{4}$ cells/well in six well culture plate.

Table 1 Primer sequences for control and target genes. Detailed description of all genes tested, primer pairs' sequences and Q-PCR conditions.

\begin{tabular}{|c|c|c|c|c|c|c|}
\hline Symbol & Accession number & Description & Primers $\left(5^{\prime}-3^{\prime}\right)$ & $\begin{array}{c}\text { Amplification } \\
\text { conditions }^{\S}\end{array}$ & $\begin{array}{l}\text { Tm } \\
\left({ }^{\circ} \mathrm{C}\right)\end{array}$ & Reference \\
\hline \multirow[t]{2}{*}{ IGFBP1 } & \multirow[t]{2}{*}{ NM_000596.2 } & \multirow{2}{*}{$\begin{array}{l}\text { Homo sapiens insulin-like } \\
\text { growth factor binding } \\
\text { protein } 1\end{array}$} & S: GAGATAACTGAGGAGGAG & $95^{\circ} \mathrm{C}, 03 \mathrm{~s}$ & \multirow[b]{2}{*}{78} & \multirow[b]{2}{*}{ (Samalecos et al. 2009) } \\
\hline & & & AS: CCAAAGGATGGAATGATC & $\begin{array}{l}59^{\circ} \mathrm{C}, 30 \mathrm{~s} \\
72^{\circ} \mathrm{C}, 90 \mathrm{~s}\end{array}$ & & \\
\hline \multirow[t]{2}{*}{$P R L$} & \multirow[t]{2}{*}{ NM_001163558.2 } & \multirow[t]{2}{*}{ Homo sapiens prolactin } & S: CTTCATTCCAGAAGTACCCT & $95^{\circ} \mathrm{C}, 03 \mathrm{~s}$ & \multirow[b]{2}{*}{80} & \\
\hline & & & AS: TCTTTCCCAGATATTGGCTT & $\begin{array}{l}60^{\circ} \mathrm{C}, 30 \mathrm{~s} \\
72^{\circ} \mathrm{C}, 90 \mathrm{~s}\end{array}$ & & \\
\hline \multirow[t]{2}{*}{ CB1 } & \multirow[t]{2}{*}{ NM_001160259.1 } & \multirow{2}{*}{$\begin{array}{l}\text { Homo sapiens cannabinoid } \\
\text { receptor } 1\end{array}$} & S: CTTCCCACAGAAATTCCC & $95^{\circ} \mathrm{C}, 03 \mathrm{~s}$ & \multirow[b]{2}{*}{87} & \multirow[b]{2}{*}{ Habayeb et al. (2008) } \\
\hline & & & AS: TACCTTCCCATCCTCAGA & $\begin{array}{l}62^{\circ} \mathrm{C}, 30 \mathrm{~s} \\
72^{\circ} \mathrm{C}, 90 \mathrm{~s}\end{array}$ & & \\
\hline \multirow[t]{2}{*}{ CB2 } & \multirow[t]{2}{*}{ NM_001841.2 } & \multirow{2}{*}{$\begin{array}{l}\text { Homo sapiens cannabinoid } \\
\text { receptor } 2\end{array}$} & S: CGTGGCTGTGCTCTATCTGA & $95^{\circ} \mathrm{C}, 03 \mathrm{~s}$ & \multirow[b]{2}{*}{87} & \multirow[b]{2}{*}{ Habayeb et al. (2008) } \\
\hline & & & AS: ATCTCGGGGCTTCTTCTTTT & $\begin{array}{l}62^{\circ} \mathrm{C}, 30 \mathrm{~s} \\
72^{\circ} \mathrm{C}, 90 \mathrm{~s}\end{array}$ & & \\
\hline \multirow[t]{2}{*}{ FAAH } & \multirow[t]{2}{*}{ NM_001441.2 } & \multirow{2}{*}{$\begin{array}{l}\text { Homo sapiens fatty acid } \\
\text { amide hydrolase }\end{array}$} & S: GGCCGTCAGCTACACTATGC & $95^{\circ} \mathrm{C}, 03 \mathrm{~s}$ & \multirow[b]{2}{*}{87} & \multirow[b]{2}{*}{ Habayeb et al. (2008) } \\
\hline & & & AS: ATCAGTCGСТCСАССТССC & $\begin{array}{l}59^{\circ} \mathrm{C}, 30 \mathrm{~s} \\
72^{\circ} \mathrm{C}, 90 \mathrm{~s}\end{array}$ & & \\
\hline \multirow[t]{2}{*}{ NAPE-PLD } & \multirow[t]{2}{*}{ NM_001122838.1 } & \multirow{2}{*}{$\begin{array}{l}\text { Homo sapiens } N \text {-acyl } \\
\text { phosphatidylethanolamine } \\
\text { phospholipase D }\end{array}$} & S: AGATGGCTGATAATGAGAA & $95^{\circ} \mathrm{C}, 03 \mathrm{~s}$ & \multirow[b]{2}{*}{72} & \\
\hline & & & AS: TTCTCСТСССАССАGTC & $\begin{array}{l}58^{\circ} \mathrm{C}, 30 \mathrm{~s} \\
72^{\circ} \mathrm{C}, 90 \mathrm{~s}\end{array}$ & & \\
\hline \multirow[t]{2}{*}{ GAPDH } & \multirow[t]{2}{*}{ NC_000012.12 } & \multirow{2}{*}{$\begin{array}{l}\text { Homo sapiens } \\
\text { glyceraldehyde-3- } \\
\text { phosphate dehydrogenase }\end{array}$} & S: AGAACATCATCCСТGССТC & $95^{\circ} \mathrm{C}, 03 \mathrm{~s}$ & \multirow[b]{2}{*}{78} & \multirow[b]{2}{*}{ Habayeb et al. (2008) } \\
\hline & & & AS: GCCAAATTCGTTGTCATACC & $\begin{array}{l}55^{\circ} \mathrm{C}, 30 \mathrm{~s} \\
72^{\circ} \mathrm{C}, 90 \mathrm{~s}\end{array}$ & & \\
\hline
\end{tabular}

${ }^{\S}$ Cycling conditions were as follows: an initial step at $95^{\circ} \mathrm{C} 3 \mathrm{~min}$ for enzyme activation in all cases, followed by up to 40 cycles of denaturation, annealing and primer extension as described; *The primers for IGFBP1, PRL and NAPE-PLD were designed in-house using Primer Premier (version 5.0 software; Premier Biosoft International, Palo Alto, CA; www.premierbiosoft.com). 
After treatment, the cells were collected in TRIzol reagent (Gibco/Invitrogen Corporation, Carlsbad, CA, USA) and RNA and protein were extracted according to the manufacturer's instructions. St-T1b and HdF cells were treated with the differentiation medium for 3 and $6 \mathrm{~d}$. To study the role of the $\mathrm{AEA}$ and the involvement of $\mathrm{CB}$ receptors on the decidualization process, cells were treated with differentiation medium in the absence or presence of AEA $(10 \mu \mathrm{M})$ plus CB1/ CB2 antagonists for $6 \mathrm{~d}$. RNA was quantified in the NanoDrop ND-1000 Spectrophotometer (NanoDrop Technologies, Inc, Wilmington, DE, USA), its quality was evaluated with the Experion RNA StdSens Kit (Bio-Rad Laboratories) and was analysed with Experion analytical software (Bio-Rad Laboratories). cDNA was obtained by reverse transcription of RNA using the iScript Select cDNA Synthesis Kit (Bio-Rad Laboratories) and it was subsequently amplified with specific primers, using KAPA SYBR FAST qPCR Master Mix 2x Kit (Kapa Biosystems, Woburn, MA, USA) in MiniOpticon RealTime PCR Detection System (Bio-Rad Laboratories), according to the kit protocol. Table 1 shows the primer sequences and the qRT-PCR conditions. The specificity of PCR product amplification was assessed by analysis of the melting curve. Gene expression was normalized with two housekeeping genes, GAPDH and $\beta-2$ microglobulin. As both genes were stable, analysis was achieved by the calculation of $\Delta \Delta \mathrm{CT}$ values using $\beta$-2 microglobulin as reference. The results are the mean of five independent experiments carried out in triplicate.

\section{Immunocytochemistry}

For immunocytochemistry studies, cells were seeded in 24-well plate on glass-coverslips, at a cellular density of $1.5 \times 10^{4}$ cells/well and fixed with cold methanol after treatment with differentiation stimulus for $6 \mathrm{~d}$. The expression of proteins was analysed using an avidin-biotin alkaline phosphatase complex technique (Vectastain ABC kit; Vector Laboratories, Burlingame, CA, USA). To prevent non-specific binding, slides were incubated in blocking serum (normal serum) and slides were incubated with primary antibodies vimentin (1:500, sc 6260; Santa Cruz Biotechnology) and cytokeratin-7 (1:100, M 7018; Dako) overnight at $4^{\circ} \mathrm{C}$. It was followed by incubation with biotinylated secondary antibody and with Vectastain ABC-AP reagent, according to the manufacturer's instructions. The reaction was developed Sigma Fast RedTM tablets (SigmaAldrich). Mayer's haematoxylin solution (Sigma-Aldrich) was used as counterstaining and slides were mounted in Aquamount medium (BDH Laboratory Supplies, PI, UK). Negative controls were performed by the replacement of the primary antibodies by rabbit IgG. The results are the mean of three independent experiments.

\section{Cell cycle analysis}

Cells were plated at a density of $5 \times 10^{4}$ cells in six well dishes and exposed to the differentiation medium in the absence or presence of AEA $(10 \mu \mathrm{M})$, plus CB1/CB2 antagonists for $6 \mathrm{~d}$. After trypsinization, cells were centrifuged $\left(260 \mathrm{~g}, 5 \mathrm{~min}, 4^{\circ} \mathrm{C}\right)$, resuspended in PBS and fixed in $70 \%$ cold ethanol. After fixation, cells were centrifuged and resuspended in $0.5 \mathrm{~mL}$
DNA staining solution $(5 \mu \mathrm{g} / \mathrm{mL}$ propidium iodide $(\mathrm{PI}), 0.1 \%$ Triton X-100 and $200 \mu \mathrm{g} / \mathrm{mL}$ DNAse-free RNAse A) overnight at $4{ }^{\circ} \mathrm{C}$. DNA content was analysed by flow cytometry based on the acquisition of 40,000 events (with a threshold of $100,000)$ in a BD Accuri C6 (Becton-Dickinson Jose, CA, USA) equipped with BD Accuri C6 software. Detectors for the three fluorescence channels (FL-1, FL-2 and FL-3) and for forward (FSC) and side (SSC) light scatter were set on a linear scale. Debris and cell aggregates were gated out, and singlets and doublets were analysed using a two-parameter plot of FL-2Area to FL-2-Width of PI fluorescence. The anti-proliferative effects were indicated by the percentage of cells in $\mathrm{G}_{0} / \mathrm{G}_{1}, \mathrm{~S}$ and $\mathrm{G}_{2} / \mathrm{M}$ phases of cell cycle.

The results are the mean of three independent experiments carried out in triplicate.

\section{Western blotting}

St-T1b cells and HdF (both non-differentiated and undergoing differentiation) were treated in the presence or absence of AEA $(10 \mu \mathrm{M})$ in six well plates, at a cellular density of $5 \times 10^{4}$ cells/ well. Cell extracts were prepared in a potassium phosphate buffer containing a cocktail of protease inhibitors [AEBSF (4-(2-aminoethyl) benzenesulphonyl fluoride hydrochloride) at $104 \mathrm{mM}$, aprotinin at $80 \mu \mathrm{M}$, bestatin at $4 \mathrm{mM}, \mathrm{E}-64$ at $1.4 \mathrm{mM}$, leupeptin at $2 \mathrm{mM}$ and pepstatin $\mathrm{A}$ at $1.5 \mathrm{mM}$ ] (Sigma-Aldrich). Protein concentrations were measured by Bradford assay. Samples $(20 \mu \mathrm{g})$ were run on $10 \%$ SDS-polyacrylamide gels and transferred to a nitrocellulose membrane. After blocking with $0.5 \%$ non-fat milk in TBS/Tween 80 for $1 \mathrm{~h}$, membranes were incubated with the primary antibody (Table 2) at $4{ }^{\circ} \mathrm{C}$ overnight. Membranes were then washed and incubated with rabbit anti-goat IgG or goat anti-rabbit IgG horseradish peroxidase-conjugated antibody and detected by enhanced chemiluminescence Western Bright ${ }^{\mathrm{TM}} \mathrm{ECL}$ and exposed to $X$-ray film. $\beta$-tubulin was used as a loading control. To quantify and compare protein levels, the density of each band was measured by densitometry. The results are the mean of three independent experiments.

\section{Evaluation of mitochondrial transmembrane potential $(\Delta \psi m)$}

For mitochondrial transmembrane potential $(\Delta \Psi \mathrm{m})$ assessment, non-differentiated and cells undergoing decidualization were

Table 2 Summary of antibodies used for the Western blotting procedures. Antibodies were from Santa Cruz Biotechnology.

\begin{tabular}{|c|c|c|c|c|c|c|}
\hline \multirow[b]{2}{*}{ Protein } & \multirow{2}{*}{$\begin{array}{c}\text { SDS- } \\
\text { Page } \\
(\%)\end{array}$} & \multicolumn{2}{|c|}{$\begin{array}{l}\text { Primary } \\
\text { antibody }\end{array}$} & \multicolumn{2}{|c|}{$\begin{array}{c}\text { Secondary } \\
\text { antibody }\end{array}$} & \multirow[b]{2}{*}{ Reference } \\
\hline & & Source & Dilution & Source & Dilution & \\
\hline CB1 & 10 & Rabbit & $1 / 100$ & Goat & $1 / 1000$ & sc-20754 \\
\hline CB2 & 10 & Rabbit & $1 / 100$ & Goat & $1 / 1000$ & sC-25494 \\
\hline NAPE-PLD & 10 & Goat & $1 / 100$ & Rabbit & $1 / 1000$ & sc- 163118 \\
\hline FAAH & 10 & Goat & $1 / 100$ & Rabbit & $1 / 1000$ & sc-26427 \\
\hline Cyclin B1 & 10 & Rabbit & $1 / 200$ & Goat & $1 / 1000$ & sC-752 \\
\hline pAkt & 10 & Rabbit & $1 / 100$ & Goat & $1 / 1000$ & SC-7985-R \\
\hline Total Akt & 10 & Rabbit & $1 / 200$ & Goat & $1 / 1000$ & sc- 8312 \\
\hline$\beta$-tubulin & 10 & Rabbit & $1 / 500$ & Goat & $1 / 1500$ & h-235 \\
\hline
\end{tabular}


treated with or without $\mathrm{AEA}(10 \mu \mathrm{M})$ and stained with $\mathrm{DiOC}_{6}(3)$ $(30 \mathrm{nM})$ for $30 \mathrm{~min}$. PI $(5 \mu \mathrm{g} / \mathrm{mL})$ was added before analysis to discriminate among viable cells that stain only with $\mathrm{DiOC}_{6}(3)$ $\left(\mathrm{DiOC}_{6}(3)^{+} / \mathrm{PI}^{-}\right)$, early apoptotic cells that lost the ability to accumulate $\operatorname{DiOC}_{6}(3)$, and therefore lost mitochondrial transmembrane potential $\left(\mathrm{DiOC}_{6}(3)^{-} / \mathrm{PI}^{-}\right)$, and late apoptotic/ necrotic cells that stain only with $\mathrm{PI}\left(\mathrm{DiOC}_{6}(3)^{-} / \mathrm{PI}^{+}\right)$. As positive control, cells were incubated with $15 \mu \mathrm{M}$ of the mitochondrial depolarizant agent carbonyl cyanide $m$-chlorophenylhydrazone (CCCP) (Sigma-Aldrich). The $\Delta \Psi \mathrm{m}$ was analysed by flow cytometry based on the acquisition of 20,000 events (with a threshold of 100,000) in a BD Accuri C6 (Becton-Dickinson Jose, CA, USA) equipped with BD Accuri C6 software. Detectors for forward (FSC) and side (SSC) light scatter were set on a linear scale, while the three fluorescence channels (FL-1, FL-2 and FL-3) were set on the logarithmic scale. FL-1 was used to measure DiOC6(3) at green fluorescence and FL-2 and FL-3 to measure PI red fluorescence. The results are the mean of three independent experiments carried out in triplicate.

\section{Statistical analysis}

Statistical analysis was performed using analysis of variance t-test or two-way ANOVA followed by Tukey's test for multiple comparisons (GraphPad PRISM version 4.0; GraphPad Software). All numerical data are expressed as mean \pm S.E.M. and differences were considered to be statistically significant when $P<0.05$.

\section{Results}

\section{Expression of decidual markers in decidualizing St-T1b and HdF cells}

In order to study the differentiation process, two endometrial cell culture systems were used, a telomerase-immortalized St-T1b and a primary culture of HdFs. In both St-T1b and HdF cell models, differentiation was induced for 3 and 6 days (d). The differentiation process was assessed by the steady-state transcript levels of specific decidual markers, the prolactin (PRL) and the insulin-like growth binding protein-1 (IGFBP1) and by morphological analysis (Fig. 1). Giemsa staining showed that non-differentiated cells from St-T1b cell line (Fig. 1A) and HdF cells (Fig. 1C) maintained the elongated fibroblastic spindle shape, whereas decidualizing cells became larger and with rounded nucleus in both St-T1b cell line (Fig. 1B) and $\mathrm{HdF}$ cells (Fig. 1D). As PRL and IGFBP1 are widely used biochemical markers of decidualization, mRNA transcript levels were analysed in non-differentiated and in differentiating cells after 3 and $6 \mathrm{~d}$ of differentiation stimulus by qRT-PCR. In both St-T1b (Fig. 1G) and $\mathrm{HdF}$ cells (Fig. 1H), the mRNA levels of the decidual markers were significantly increased, particularly in cells induced to decidualize for $6 \mathrm{~d}$. Therefore, the subsequent studies were conducted in cells undergoing differentiation for $6 \mathrm{~d}$.

\section{Characterization of the ECS in St-T1b and HdF cells}

The expression of major enzymes involved in AEA metabolism, mRNA transcript and protein levels of NAPE-PLD, FAAH and cannabinoid receptors, CB1 and CB2, were investigated by qRT-PCR and Western blotting analysis respectively (Fig. 2). In St-T1b cells (Fig. 2A and D), mRNA and protein levels of CB1 receptor were not affected upon differentiation, and it has been found that these cells do not express CB2 receptor. No differences were observed in NAPE-PLD expression, whereas FAAH expression was upregulated in cells undergoing differentiation. In HdF cells, a fully functional ECS biochemical machinery was found (Fig. 2B and E). CB1 mRNA transcript and protein levels were upregulated in differentiating cells, whereas CB2 expression remained unaffected. Regarding the metabolic enzymes, NAPEPLD expression remained constant during in vitro differentiation, while FAAH was upregulated at mRNA transcript and protein levels.
A

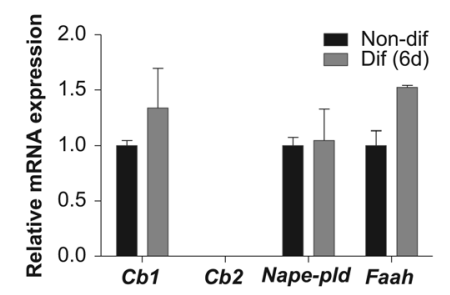

C

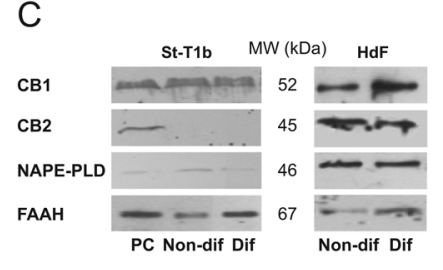

www.reproduction-online.org
B
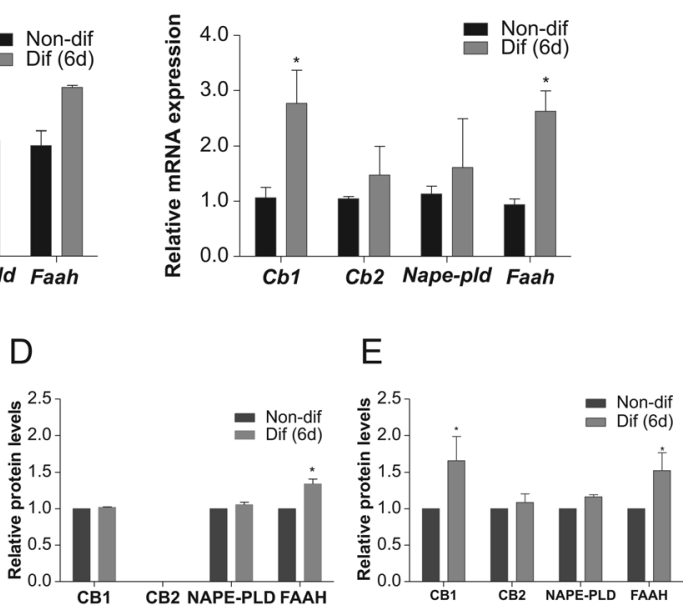

Figure 2 Characterization of the endocannabinoid system (ECS) by western blotting and qRT-PCR in non-differentiated (non-dif) and differentiating cells (dif) treated for 6 days with differentiation stimulus. mRNA transcript levels of the $\mathrm{CB}$ receptors and the main metabolic enzymes of AEA in St-T1b cell line (A) and HdF cells (B). (C) Protein levels of the principal members of the ECS and western blotting quantification in both St-T1b (D) and $\mathrm{HdF}(\mathrm{E})$ cells. In HdF, CB1 expression was increased in cells undergoing decidualization. St-T1b cell line does not express CB2 receptor. (PC, positive control) $\left({ }^{*} P<0.05\right.$ vs non-dif) ( $n=3$; two-way ANOVA, Tukey's multiple comparisons). 
A

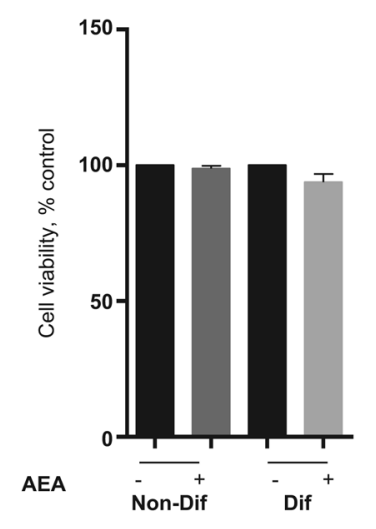

C

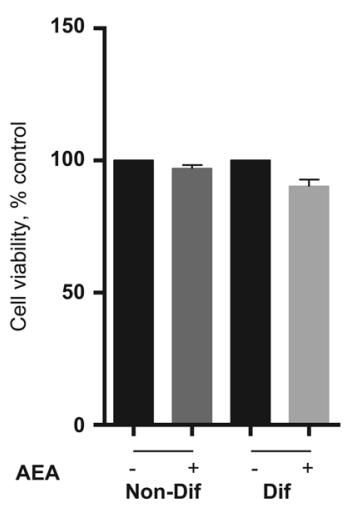

B

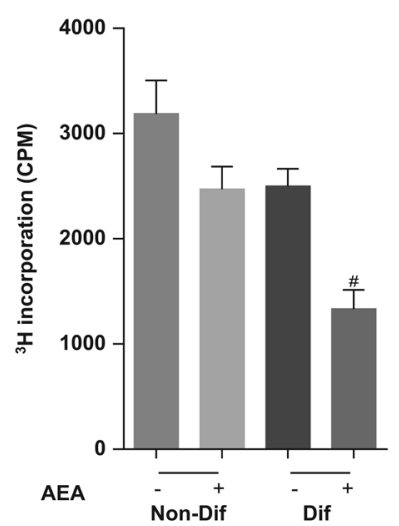

D

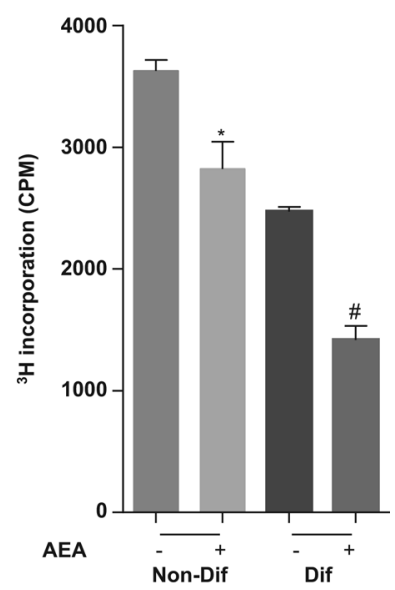

Figure 3 Effect of AEA in non-differentiated (non-dif) and differentiating cell (dif) viability and proliferation. Differentiation cells were treated with deciduogenic stimulus (CAMP, MPA and $E_{2}$ ) in the absence or presence of AEA $(10 \mu \mathrm{M})$. Cell viability and the rate of DNA synthesis were assessed by MTT and $\left[{ }^{3} \mathrm{H}\right]$-thymidine incorporation assay respectively. AEA did not affect non-differentiated and differentiating St-T1b cells viability (A). In St-T1b cell line, AEA decreased the rate of DNA synthesis (B). In HdF cells, AEA did not affect viability of non-differentiated and of cells undergoing differentiation (C), but significantly decreased DNA synthesis in non-differentiated and in differentiating HdF cells (D).

$\left({ }^{*} P<0.05\right.$ vs non-dif; ${ }^{\sharp} P<0.05$ vs dif) $(n=5 ;$ t-test).

\section{AEA effect on human endometrial cell viability and cell proliferation}

Non-differentiated cells or cells exposed to the differentiation medium were cultured in the presence or absence of AEA $(10 \mu \mathrm{M})$ for $6 \mathrm{~d}$, and cell viability was assessed by MTT assay. In the culture conditions used, AEA did not affect cell viability of non-differentiated nor of cells undergoing in vitro differentiation, in both St-T1b (Fig. 3A) and HdF (Fig. 3C) cell models. Therefore, this concentration was chosen as, on the conditions used, it does not affect cell viability, and, as it was reported previously, impairs in vitro stromal cell differentiation in the rat model.

The decidualization process involves extensive proliferation and differentiation of HESCs; thus, to investigate the role of AEA on the rate of DNA synthesis, $\left[{ }^{3} \mathrm{H}\right]$-thymidine incorporation was examined in both non-differentiated and differentiating cells, in the presence or absence of AEA $(10 \mu \mathrm{M})$ for St-T1b (Fig. 3B) and $\mathrm{HdF}$ (Fig. 3D) cell models. In non-differentiated cells, AEA caused a decrease in $\left[{ }^{3} \mathrm{H}\right]$-thymidine incorporation of $28 \%$ in St-T1b and of $30 \%$ in HdF cells compared with non-treated cells. As expected, cell proliferation was reduced in differentiating cells compared with non-differentiated cells. However, in cells undergoing differentiation, AEA treatment markedly decreased the rate of DNA synthesis by $40 \%$ compared with differentiating cells, in both cell models.

In order to understand the anti-proliferative effect, AEA impact on cell cycle progression was explored (Table 3). In non-differentiated cells, AEA treatment led to a significant cell cycle arrest at $\mathrm{G}_{2} / \mathrm{M}$ phase, both in St-T1b (12.37\%) and in HdF cells (34.38\%) compared with non-differentiated cells ( $8.51 \%$ and $30.16 \%$ ). Upon differentiation, stromal cells cease to proliferate; thus, the differentiation stimulus caused a significant increase in cells arrested at the $G_{0} / G_{1}$ phase and a decrease in the cellular content at the $S$ phase, in both cell models. In St-T1b cells exposed to AEA during differentiation treatment, a decrease in the cellular content at the $\mathrm{G}_{0} / \mathrm{G}_{1}$ phase compared with cells undergoing differentiation $(84.77 \%$ vs $92.15 \%$ respectively) and a significant arrest

Table 3 Impact of AEA on cell cycle progression in St-T1b and HdF cells. Analysis of singlets ( $n$ ) and duplets (2n) in FL2-A and FL2-W fluorescence channels are presented. The data represents $n=3,2$-way ANOVA, Tukey's multiple comparisons.

\begin{tabular}{|c|c|c|c|c|c|c|}
\hline & Non-dif & Non-dif (AEA) & Dif & Dif (AEA) & $\mathrm{AEA}+\mathrm{AM} 281$ & $\mathrm{AEA}+\mathrm{AM} 630$ \\
\hline \multicolumn{7}{|c|}{ St-T1b cells } \\
\hline $\mathrm{G} 0 / \mathrm{G} 1$ & $84.59 \pm 1.48$ & $82.00 \pm 0.80$ & $92.15 \pm 0.65^{*}$ & $84.77 \pm 1.70^{\#}$ & $90.13 \pm 0.92^{\S}$ & \\
\hline S & $6.90 \pm 2.34$ & $5.63 \pm 1.49$ & $1.63 \pm 0.42 *$ & $1.88 \pm 0.41$ & $1.83 \pm 0.70$ & \\
\hline $\mathrm{G} 2 / \mathrm{M}$ & $8.51 \pm 1.40$ & $12.37 \pm 0.99 *$ & $6.22 \pm 0.62$ & $13.38 \pm 1.48^{\#}$ & $8.04 \pm 0.54^{\S}$ & \\
\hline $\mathrm{n}$ & $98.73 \% \pm 0.29$ & $96.02 \% \pm 0.36$ & $98.68 \% \pm 0.44$ & $96.67 \% \pm 0.49$ & $96.96 \% \pm 0.14$ & \\
\hline $2 n$ & $0.63 \% \pm 0.41$ & $1.28 \% \pm 0.65 *$ & $0.66 \% \pm 0.39$ & $1.78 \% \pm 0.64^{\#}$ & $1.54 \% \pm 0.14^{\#}$ & \\
\hline \multicolumn{7}{|l|}{ HdF cells } \\
\hline G0/G1 & $65.05 \pm 0.58$ & $62.13 \pm 0.52$ & $70.51 \pm 1.20^{*}$ & $55.32 \pm 1.74^{\#}$ & $67.20 \pm 2.07^{\S}$ & $57.20 \pm 2.05$ \\
\hline $\mathrm{S}$ & $5.45 \pm 0.66$ & $3.49 \pm 0.32$ & $2.00 \pm 0.45$ & $4.29 \pm 1.21$ & $4.63 \pm 0.43$ & $4.95 \pm 0.32$ \\
\hline $\mathrm{G} 2 / \mathrm{M}$ & $30.16 \pm 1.04$ & $34.38 \pm 0.26^{*}$ & $26.91 \pm 0.60$ & $40.40 \pm 1.12^{\#}$ & $28.17 \pm 1.64^{\S}$ & $37.85 \pm 0.94$ \\
\hline $\mathrm{n}$ & $94.24 \% \pm 1.02$ & $90.91 \% \pm 0.95 *$ & $95.25 \% \pm 0.60$ & $88.26 \% \pm 1.87^{\#}$ & $89.00 \% \pm 1.39^{\#}$ & $88.00 \% \pm 1.92^{\#}$ \\
\hline $2 n$ & $5.76 \% \pm 0.66$ & $9.10 \% \pm 1.02 *$ & $4.74 \% \pm 0.20$ & $11.74 \% \pm 1.90^{\#}$ & $11.00 \% \pm 1.64^{\#}$ & $12.00 \% \pm 1.04$ \\
\hline
\end{tabular}

${ }^{*} P<0.05$ vs Non-dif; ${ }^{*} P<0.05$ vs Dif; ${ }^{\S} P<0.05$ vs Dif (AEA). 

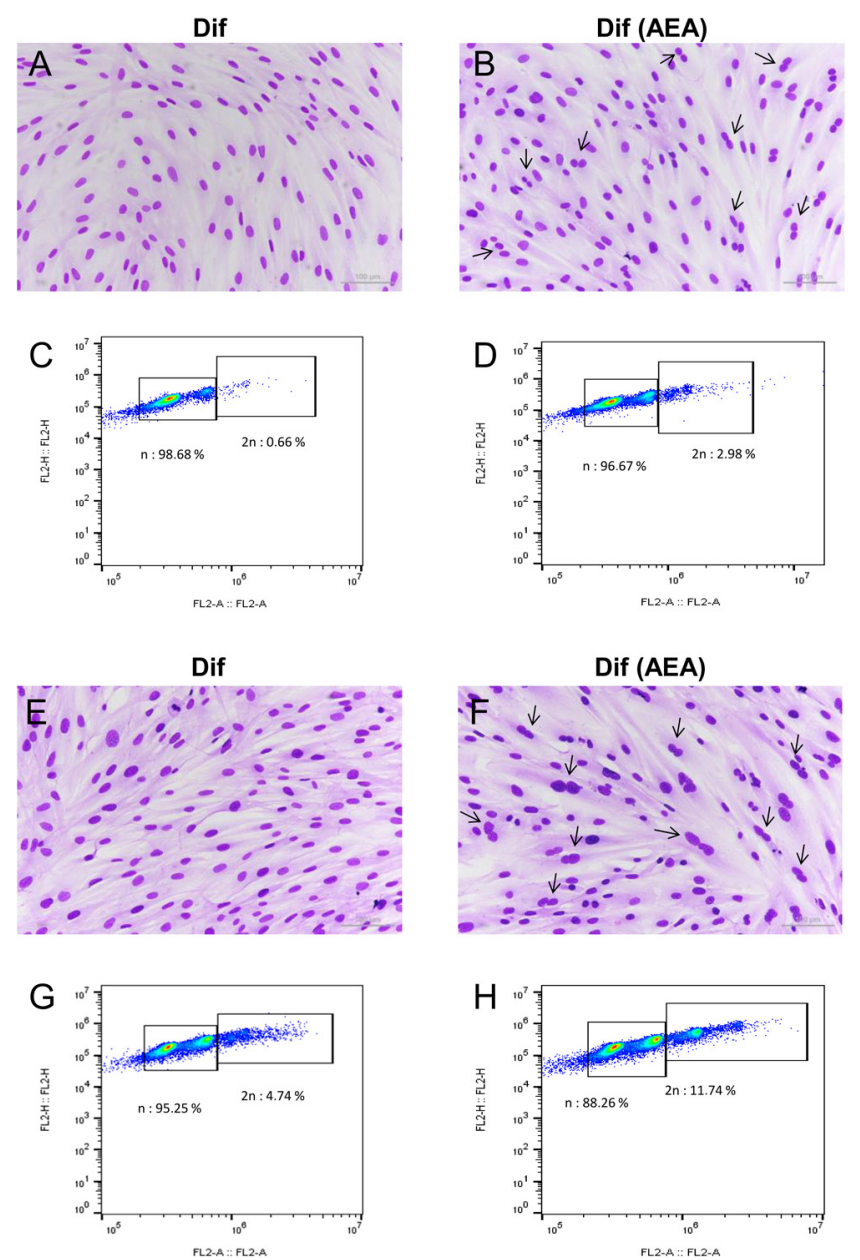

Figure 4 AEA treatment induced an increase in bi-nucleated cells. St-T1b cells undergoing differentiation (A). In St-T1b cells undergoing differentiation, AEA treatment led to the appearance of bi-nucleated cells (arrows) as shown in Giemsa staining. Representative FACS plots from flow cytometric studies through analysis of FL2-A and FL2-W fluorescence channels, representing singlets $(n)$ and duplets $(2 n)$ in differentiating cells $(\mathrm{C})$ and in differentiating cells treated with AEA (D). In HdF cells, a significant accumulation of bi-nucleated cells in AEA-treated cells was observed through Giemsa staining when comparing differentiated cells $(\mathrm{E})$ and differentiated AEA-treated cells (F). FACS plots of differentiating HdF cells (G) and cells exposed to differentiation stimulus in the presence of AEA $(H)$. Arrows indicate the presence of bi-nucleated cells. ( $n$ : singlets; $2 n$ : duplets, analysed by FL2-A and FL2-W channels).

at $G_{2} / M$ phase when compared with differentiating cells have been found. A similar pattern of cell cycle distribution was found in HdF cells. Consistently, in $\mathrm{HdF}$ cells, during in vitro differentiation, AEA-induced a decrease in the cellular content at $\mathrm{G}_{0} / \mathrm{G}_{1}$ phase when compared with differentiating cells $(55.32 \%$ vs $70.51 \%$ respectively), and a significant cell cycle arrest at $\mathrm{G}_{2} / \mathrm{M}$ phase (40.40 vs $26.91 \%$ respectively). Analysis of decidualizing cells treated with AEA plus AM281, a selective CB1 antagonist, showed a cell cycle distribution similar to differentiating cells, such as $\mathrm{G}_{0} / \mathrm{G}_{1}$ arrest and a decrease in $\mathrm{G}_{2} / \mathrm{M}$ phase, in both cell models. The effect of AEA in the presence of AM630, a selective CB2 antagonist, was also studied in HdF cells, although no significant difference in cell cycle distribution patterns was observed when compared with AEA-treated differentiating cells.

Unexpectedly, it was noticed by Giemsa staining that in AEA-treated cells, there was an increased number of bi-nucleated cells (Fig. 4B and F). The flow cytometric study, through analysis of singlets (n) and duplets (2n) in FL-2A and FL-2W channels, confirmed the increased number of bi-nucleated cells $(2 n)$ upon AEA treatment (Fig. 4D and $\mathrm{H}$ ). In both non-differentiated and differentiating cells, AEA treatment induced at least a two-fold increase in the number of bi-nucleated cells, in St-T1 b and HdF cells. In contrast to St-T1 b, approximately $6 \%$ of non-differentiated $\mathrm{HdF}$ cells were $2 n$ (Table 3 ). In addition, it was observed that pre-incubation with CB1 receptor antagonist did not prevent the appearance of bi-nucleated cells in both cell models.

To clarify the mechanism underlying AEA-induced retention at $\mathrm{G}_{2} / \mathrm{M}$, the expression of cyclin $B 1$, a key regulator of $\mathrm{G}_{2} / \mathrm{M}$ transition was investigated by Western blotting. As shown in Fig. $5 \mathrm{~A}$ and $\mathrm{B}$, in AEA-treated St-T1b and HdF cells respectively cyclin B1 protein levels were not altered neither in non-differentiated nor in cells undergoing decidualization. To further explore the signalling pathway underlying AEA-induced effect, Akt activation was investigated by Western blotting. AEA reduced Akt phosphorylation in both non-differentiated and differentiating cells compared with respective controls, in both cell models (Fig. 5). In addition, as in rats, it has been suggested that mitochondria play a crucial role in decidual polyploidization (Ma et al. 2011). The impact of AEA in mitochondrial transmembrane potential $(\Delta \Psi \mathrm{m})$ was studied by flow cytometry on nondifferentiated and in cells undergoing differentiation. However, in both cell types and in St-T1 b and HdF cells (Table 4), AEA did not induce any alteration in the $\Delta \Psi \mathrm{m}$.

\section{AEA interferes with cell differentiation}

To explore the role of AEA upon the differentiation process, both St-T1b and HdF cells were induced to differentiate in the absence or presence of AEA $(10 \mu \mathrm{M})$ for $6 \mathrm{~d}$, and mRNA expression of IGFBP1 and PRL genes was analysed by qRT-PCR. As expected, mRNA levels of both genes were significantly higher in decidualizing cells compared with non-differentiated cells. However, as shown in Fig. 6, the transcript levels of both decidual markers were significantly decreased in cells induced to differentiate in the presence of AEA, to similar levels of those found in non-differentiated cells. To investigate the influence of cannabinoid receptors, cells were exposed to the differentiation stimulus in the presence of AEA $(10 \mu \mathrm{M})$ and pre-incubated with a CB1 antagonist (AM281) or a CB2 antagonist (AM630). In both St-T1B (Fig. 6A) and HdF (Fig. 6B) cells, pre-incubation with 
A

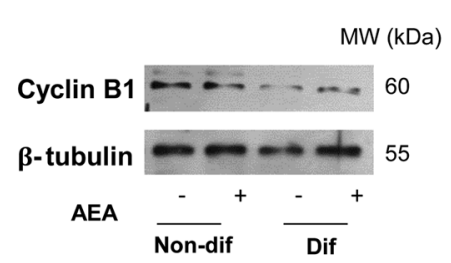

C

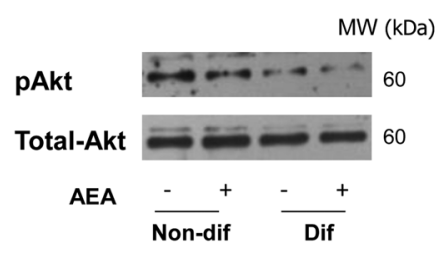

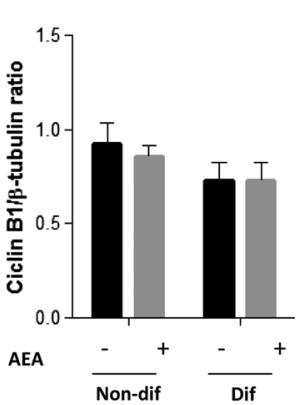

B

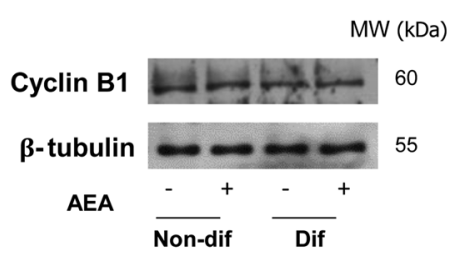

D
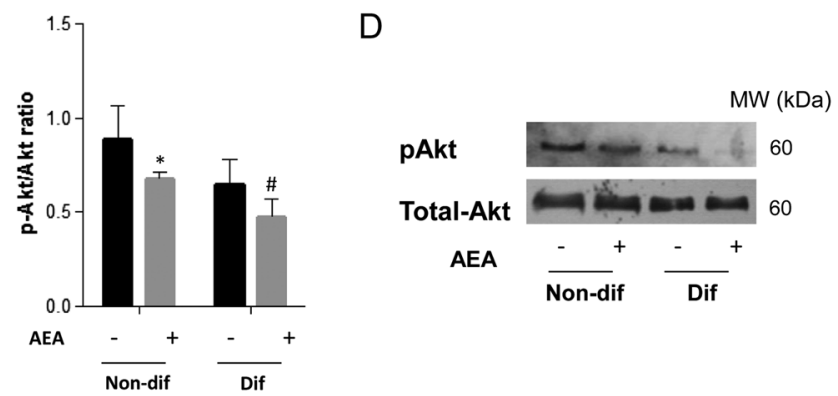
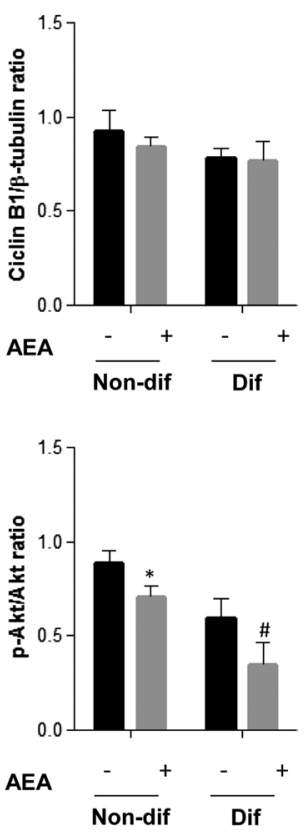

Figure 5 Effect of AEA on cyclin B1 and Akt protein levels by Western blotting. Cyclin B1 expression was not altered by AEA treatment in both non-differentiated and cells undergoing differentiation in St-T1b cell line (A) and HdF cells (B). However, AEA reduced the activation of Akt in both non-differentiated and cells undergoing decidualization in St-T1b cell line (C) and HdF cells (D). $\left({ }^{*} P<0.05\right.$ vs non-dif; ${ }^{*} P<0.05$ vs dif) ( $n=3$, two-way ANOVA, Tukey's multiple comparisons).

AM281 significantly counteracted the AEA reduction on decidual marker gene expression to levels similar of control decidualizing cells. The contribution of CB2 in the case of HdF was also studied, although the expression of the genes encoding the decidual markers was not affected.

\section{Discussion}

Decidualization involves extensive stromal cell proliferation and differentiation, which is followed by programmed cell death, although the underlying molecular mechanisms remain unclear. eCBs are novel lipid mediators and may be important players in the molecular network composed by hormones, cytokines and growth factors that orchestrates human decidualization. It is known that AEA mediates several cellular events ranging from cell proliferation,

Table 4 Effect of AEA on mitochondrial transmembrane potential $(\Delta \Psi \mathrm{m})$ in St-T1b and HdF cells. Viable cells that stain only with $\mathrm{DiOC}_{6}(3)\left(\mathrm{DiOC}_{6}(3)^{+} / \mathrm{Pl}^{-}\right)$. Early apoptotic cells that lost mitochondrial transmembrane potential and therefore the ability to accumulate $\mathrm{DiOC}_{6}(3)\left(\mathrm{DiOC}_{6}(3)^{-} / \mathrm{PI}^{-}\right)$.

\begin{tabular}{|c|c|c|c|c|}
\hline & Non-dif & Non-dif (AEA) & Dif & Dif (AEA) \\
\hline \multicolumn{5}{|l|}{ St-T1b cells } \\
\hline Viable & $97.45 \pm 0.40$ & $97.21 \pm 0.23$ & $96.35 \pm 0.20$ & $97.14 \pm 0.18$ \\
\hline$\Delta \psi \mathrm{m}$ loss & $2.55 \pm 0.40$ & $2.79 \pm 0.20$ & $3.65 \pm 0.20$ & $2.86 \pm 0.19$ \\
\hline \multicolumn{5}{|c|}{ HdF cells } \\
\hline Viable & $97.00 \pm 0.33$ & $96.83 \pm 0.33$ & $98.01 \pm 0.28$ & $98.11 \pm 0.31$ \\
\hline$\Delta \psi \mathrm{m}$ loss & $3.00 \pm 0.33$ & $3.17 \pm 0.33$ & $1.99 \pm 0.28$ & $1.89 \pm 0.30$ \\
\hline
\end{tabular}

Reproduction (2016) 152 351-361 differentiation and apoptosis, dependent on the biological system/environment and cellular context (Fonseca et al. 2013b). It was recently shown that AEA levels are lower in cells undergoing differentiation compared with non-differentiated cells (Almada et al. 2016). Nevertheless, its role upon the human decidualization is not yet disclosed. In rats, it was described previously that the metabolic enzymes expressed in decidual cells are the main controllers of eCB levels throughout pregnancy (Fonseca et al. 2010). In addition, AEA induces apoptosis in rat primary decidual cell cultures (Fonseca et al. 2013a, Almada et al. 2015) and interferes with decidualization process (Fonseca et al. 2015). Herein, a novel role for AEA as a modulator of human decidualization was proposed, through an effect on both endometrial stromal cell proliferation and differentiation.

In this study, the ECS was characterized in St-T1b and HdF cells, in both non-differentiated cells and in cells undergoing differentiation. As reported previously, $\mathrm{HdF}$ cells isolated from term decidua are considered undifferentiated fibroblast-like cells (Richards et al. 1995). On the other hand, it was also reported that St-T1b cell line expresses the appropriate phenotypic endometrial stromal cell markers and their decidual response closely mimics that of primary cultures (Samalecos et al. 2009). Both models have been used to investigate in vitro decidualization in several studies (Richards et al. 1995, Samalecos et al. 2009).

In opposite to St-T1b cell line, CB1 expression was upregulated in $\mathrm{HdF}$ decidualizing cells, which is in 

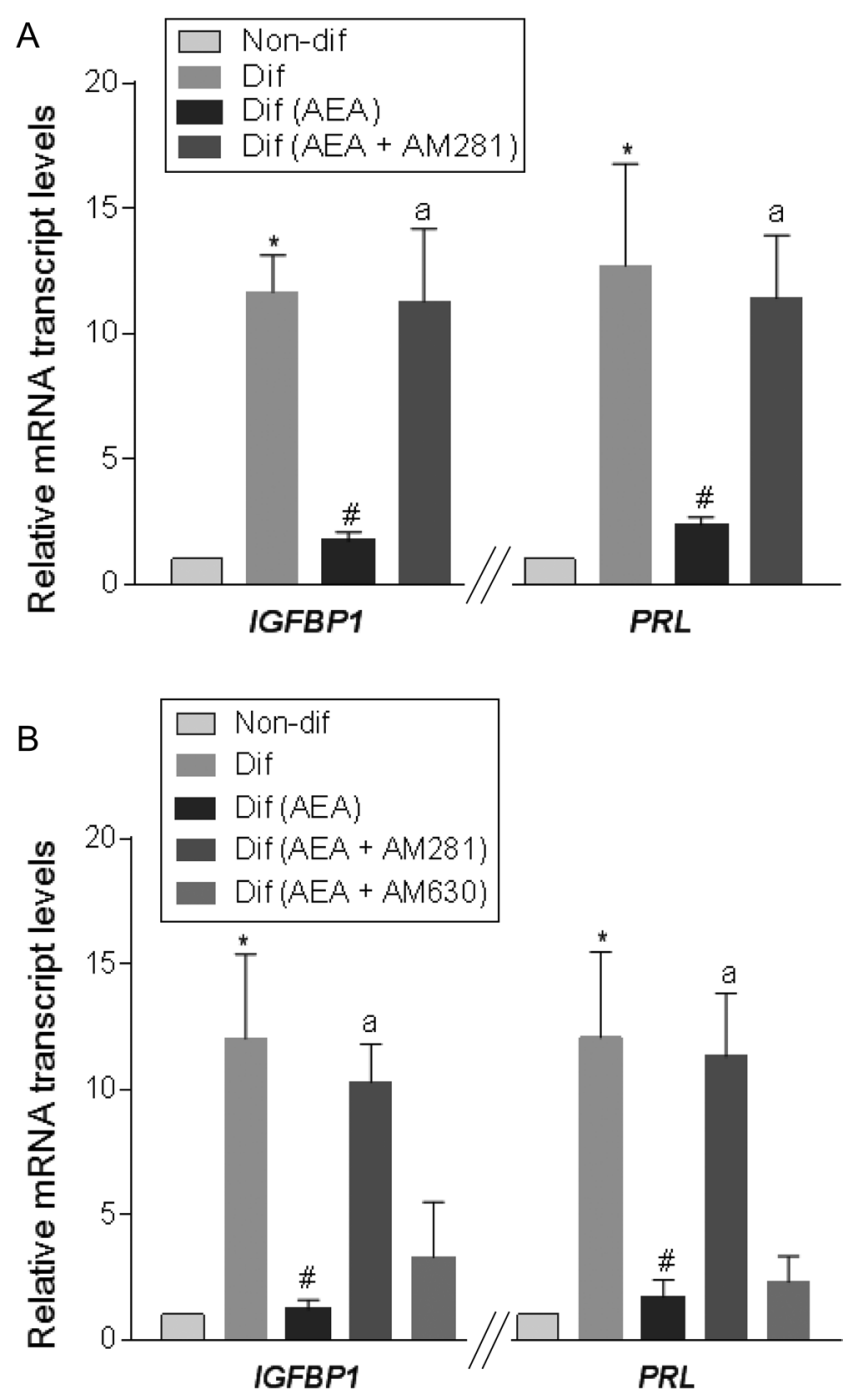

Figure 6 mRNA transcript levels of specific human decidual marker genes. Upon AEA treatment, IGFBP1 and PRL expression was significantly decreased in St-T1b cell line (A) and HdF cells (B). AEA induced decreased in mRNA expression of both markers reverted by CB1 antagonist, AM281, in both St-T1b and HdF cells. In HdF, no reversion was observed in the case of AM630, the CB2 antagonist. $\left({ }^{*} P<0.05\right.$ vs non-dif; ${ }^{\sharp} P<0.05$ vs dif; a $P<0.05$ vs dif (AEA) $(n=5$, two-way ANOVA, Tukey's multiple comparisons).

agreement with a previous study (Moghadam et al. 2005). In this regard, it is possible that the endocrine environment to which HdF cells have been exposed may influence CB1 expression. In addition, it was shown that $\mathrm{FAAH}$ expression was upregulated during the decidualization process in vitro, whereas NAPEPLD expression remained constant in both cell models. These findings are consistent with the expression of the metabolic enzymes in human endometrium during the menstrual cycle, in which FAAH protein levels are higher in the secretory phase, which corresponds to the differentiation of stromal cells, compared with the proliferative phase (Taylor et al. 2010). Moreover, our findings further support the recognized role of FAAH, the main AEA degrading enzyme, as a metabolic gatekeeper decreasing AEA uterine levels and promoting the implantation process (Maccarrone \& Finazzi-Agro 2004).

Although St-T1b cells did not express CB2 receptor, $\mathrm{HdF}$ cell model express both cannabinoids receptors. Moreover, as it was herein shown in HdF model, CB1 receptor appears to be mediating AEA effects during in vitro decidualization, rather than $\mathrm{CB} 2$ that did not revert the inhibitory effect of this eCB. Therefore, these cell models complement each other to study the role of the AEA during this process. Nevertheless, since St-T1b does not express CB2, it cannot be used by itself to investigate the effect of other eCBs that might also activate CB2 during in vitro decidualization.

In addition, it was demonstrated that AEA inhibited endometrial cell proliferation supported by a reduction on the rate of DNA synthesis, cell cycle arrest at the $\mathrm{G}_{2} / \mathrm{M}$ phase and accumulation of bi-nucleated cells. The latter features were observed in non-differentiated and in cells undergoing decidualization, in both cell models, suggesting that it is not cell specific. In addition, it was found that AEA treatment did not affect cyclin B1 expression, whereas it reduced phosphorylation of Akt, a signalling pathway involved in cell survival and proliferation (Song et al. 2005). In fact, it has been reported that diminished Akt phosphorylation is associated with inhibition of actin polymerization and consequently cytokinesis failure, appearance of multinucleated cells and cell growth inhibition (Matesic et al. 2006). Moreover, as described previously, the accumulation of bi-nucleated cells and cell cycle arrest at the $\mathrm{G}_{2} / \mathrm{M}$ phase may also result from aberrant mitosis and failed cytokinesis, or defects in mitotic spindle checkpoint (Jordan \& Wilson 2004, Lee et al. 2009, Kundu et al. 2014). Therefore, it may be suggested that although cells progress through $\mathrm{G}_{2} / \mathrm{M}$ phase, they may fail to undergo cytokinesis, probably due to a direct effect of AEA.

Interestingly, the association of polyploidy with the decidualization process has already been reported. In rodents, endoreduplication (polyploidy) of endometrial stromal cells is well established (Tan et al. 2002, Tan et al. 2004, Das 2009). In fact, it has been reported that decidual polyploidy develops as mono- or bi-nucleated cells due to blockage in $\mathrm{G}_{2} / \mathrm{M}$ phase of the cell cycle, as a result of a mitotic cycle without cytokinesis (Sroga et al. 2012). Moreover, decidua with insufficient polyploidy limits implantation (Das 2009, Sroga et al. 2012), whereas aberrant decidual polyploidy was also shown to be detrimental to this process (Gao et al. 2015). In human decidualization, the presence of bi-nucleated cells has been reported by Tang et al. $(1993,1994)$ and is a topic of increasing recognition in the literature; however, their significance has never been addressed. Nevertheless, in the conditions used, AEAinduced bi-nucleation in both non-differentiated and in 
cells undergoing decidualization and was independent of $\mathrm{CB} 1$ receptor activation.

Decidualization is a key event for successful implantation, in which endometrial stromal cells cease to proliferate and undergo a differentiation process into decidual cells, being the latter induced by an increase in intracellular cAMP levels. In this study, it was demonstrated that AEA significantly decreased the decidual markers transcript levels, $P R L$ and IGFBP 1 , upon in vitro decidualization, in a mechanism dependent on CB1 activation. As CB1 activation is known to inhibit adenylate cyclase, it is likely that the AEA inhibitory effect on decidualization is mediated through CB1induced decrease in CAMP production. In addition, it was shown that AEA prevented cell cycle arrest at $\mathrm{G}_{0} / \mathrm{G}_{1}$ phase during in vitro decidualization, which may hamper cell differentiation. Reinforcing the involvement of CB1 receptor on the inhibitory effect caused by AEA, it was shown that the pattern of cell cycle distribution of cells treated with a selective CB1 antagonist (AM281) plus AEA was similar to the untreated cells undergoing differentiation. Thus, our findings suggest that AEA may be a negative modulator of human stromal cell differentiation. Moghadam et al. (2005) showed previously that WIN55,212-2, a full CB1 agonist, inhibited decidualization through CB1 by triggering an apoptotic pathway. However, in our conditions, AEA effect was not accompanied by cell death. Despite in rats, it has been suggested that mitochondria may play a role in polyploidization, no alterations in the mitochondrial transmembrane potential were observed.

Understanding the molecular signature that underlies the role of AEA on endometrial stromal cells further elucidates the cellular and molecular basis that governs decidualization. Two major breakthroughs are highlighted in this study. On the one hand, AEA inhibits decidual stromal cell proliferation and leads to the appearance of bi-nucleated cells, which may consequently impair stromal cell differentiation. On the other hand, AEA also act as a negative modulator of endometrial stromal cell differentiation through a CB1dependent mechanism. Moreover, it is widely accepted that AEA levels are mainly regulated by FAAH activity. Altogether, our findings corroborate that a balance tone of AEA uterine levels is crucial for human decidualization, and thus elevated levels of this eCB, due to cannabinoids consumption or to FAAH deregulation, may impair this process. We also suggest that AEA may be a central tie bridging both steps of the decidual program, stromal cell proliferation and differentiation. Decidualization is a remarkable feature of human reproduction. It is known that impaired decidualization process is associated with a variety of reproductive disorders, ranging from infertility, recurrent miscarriage, uteroplacental interaction disorders. Nowadays, failure of the endometrium to achieve a receptive state is considered as a major cause of infertility as well as the rate-limiting step in assisted reproductive technology. Therefore, unveiling the molecular mechanisms that underpin the decidualization process is of great importance to improve reproductive outcome.

\section{Declaration of interests}

The authors declare that there is no conflict of interest that could be perceived as prejudicing the impartiality of the research reported.

\section{Funding}

This work was funded by Fundação para a Ciência e Tecnologia (FCT) under the project UID/Multi/04378/2013. The grants provided were to Almada M (SFRH/BD/81561/2011), Fonseca BM (SFRH/BPD/72958/2010) and Cristina Amaral (SFRH/BPD/ 98304/2013).

\section{References}

Almada M, Cunha S, Fonseca BM, Amaral C, Piscitelli F, Di Marzo V, Correia-da-Silva G \& Teixeira N 2016 Anandamide interferes with human endometrial stromal-derived cell differentiation: An effect dependent on inhibition of cyclooxygenase-2 expression and prostaglandin E release. Biofactors 42 277-286. (doi:10.1002/biof.1270)

Almada M, Piscitelli F, Fonseca BM, Di Marzo V, Correia-da-Silva G \& Teixeira N 2015 Anandamide and decidual remodelling: COX-2 oxidative metabolism as a key regulator. Biochimica et Biophysica Acta 1851 1473-1481. (doi:10.1016/j.bbalip.2015.08.011)

Das SK 2009 Cell cycle regulatory control for uterine stromal cell decidualization in implantation. Reproduction 137 889-899. (doi:10.1530/REP-08-0539)

Fonseca BM, Correia-da-Silva G, Taylor AH, Lam PM, Marczylo TH, Konje JC, Bell SC \& Teixeira NA 2010 N-acylethanolamine levels and expression of their metabolizing enzymes during pregnancy. Endocrinology 151 3965-3974. (doi:10.1210/en.2009-1424)

Fonseca BM, Correia-da-Silva G \& Teixeira NA 2013a The endocannabinoid anandamide induces apoptosis of rat decidual cells through a mechanism involving ceramide synthesis and p38 MAPK activation. Apoptosis 18 1526-1535. (doi:10.1007/s10495-013-0892-9)

Fonseca BM, Costa MA, Almada M, Correia-da-Silva G \& Teixeira NA 2013b Endogenous cannabinoids revisited: a biochemistry perspective. Prostaglandins Other Lipid Mediators 102-103 13-30. (doi:10.1016/j. prostaglandins.2013.02.002)

Fonseca BM, Correia-da-Silva G \& Teixeira NA 2015 Anandamide restricts uterine stromal differentiation and is critical for complete decidualization. Molecular and Cellular Endocrinology 411 167-176. (doi:10.1016/j.mce.2015.04.024)

Gao F, Bian F, Ma X, Kalinichenko VV \& Das SK 2015 Control of regional decidualization in implantation: role of FoxM1 downstream of Hoxa10 and cyclin D3. Science Reports 5 13863. (doi:10.1038/srep13863)

Gellersen B \& Brosens J 2003 Cyclic AMP and progesterone receptor cross-talk in human endometrium: a decidualizing affair. Journal of Endocrinology 178 357-372. (doi:10.1677/joe.0.1780357)

Gellersen B \& Brosens J 2014 Cyclic decidualization of the human endometrium in reproductive health and failure. Endocrine Reviews 35 851-905. (doi:10.1210/er.2014-1045)

Habayeb OM, Taylor AH, Bell SC, Taylor DJ \& Konje JC 2008 Expression of the endocannabinoid system in human first trimester placenta and its role in trophoblast proliferation. Endocrinology $\mathbf{1 4 9} 5052-5060$. (doi:10.1210/en.2007-1799)

Jordan MA \& Wilson L 2004 Microtubules as a target for anticancer drugs. Nature Reviews Cancer 4 253-265. (doi:10.1038/nrc1317)

Kundu S, Kim TH, Yoon JH, Shin HS, Lee J, Jung JH \& Kim HS 2014 Viriditoxin regulates apoptosis and autophagy via mitotic catastrophe 
and microtubule formation in human prostate cancer cells. International Journal of Oncology 45 2331-2340. (doi:10.3892/ijo.2014.2659)

Lee HO, Davidson JM \& Duronio RJ 2009 Endoreplication: polyploidy with purpose. Genes \& Development 23 2461-2477. (doi:10.1101/ gad.1829209)

Ma X, Gao F, Rusie A, Hemingway J, Ostmann AB, Sroga JM, Jegga AG \& Das SK 2011 Decidual cell polyploidization necessitates mitochondrial activity. PLOS ONE 6 e26774. (doi:10.1371/journal. pone.0026774)

Maccarrone M \& Finazzi-Agro A 2004 Anandamide hydrolase: a guardian angel of human reproduction? Trends in Pharmacological Sciences 25 353-357. (doi:10.1016/j.tips.2004.05.002)

Matesic DF, Villio KN, Folse SL, Garcia EL, Cutler SJ \& Cutler HG 2006 Inhibition of cytokinesis and akt phosphorylation by chaetoglobosin $\mathrm{K}$ in ras-transformed epithelial cells. Cancer Chemotherapy and Pharmacology 57 741-754. (doi:10.1007/s00280-0050113-5)

Moghadam KK, Kessler CA, Schroeder JK, Buckley AR, Brar AK \& Handwerger S 2005 Cannabinoid receptor I activation markedly inhibits human decidualization. Molecular and Cellular Endocrinology 229 65-74. (doi:10.1016/j.mce.2004.09.007)

Norwitz ER, Schust DJ \& Fisher SJ 2001 Implantation and the survival of early pregnancy. New England Journal of Medicine 345 1400-1408. (doi:10.1056/NEJMra000763)

Richards RG, Brar AK, Frank GR, Hartman SM \& Jikihara H 1995 Fibroblast cells from term human decidua closely resemble endometrial stromal cells: induction of prolactin and insulin-like growth factor binding protein-1 expression. Biology of Reproduction 52 609-615. (doi:10.1095/biolreprod52.3.609)

Samalecos A, Reimann K, Wittmann S, Schulte HM, Brosens JJ Bamberger AM \& Gellersen B 2009 Characterization of a novel telomerase-immortalized human endometrial stromal cell line, St-T1b. Reproductive Biology and Endocrinology 7 76. (doi:10.1186/14777827-7-76)

Song G, Ouyang G \& Bao S 2005 The activation of Akt/PKB signaling pathway and cell survival. Journal of Cellular and Molecular Medicine $\mathbf{9}$ 59-71. (doi:10.1111/j.1582-4934.2005.tb00337.x)

Sroga JM, Gao F, Ma X \& Das SK 2012 Overexpression of cyclin D3 improves decidualization defects in Hoxa-10(-/-) mice. Endocrinology 153 5575-5586. (doi:10.1210/en.2012-1528)
Strowitzki T, Germeyer A, Popovici R \& von Wolff M 2006 The human endometrium as a fertility-determining factor. Human Reproduction Update 12 617-630. (doi:10.1093/humupd/dml033)

Tan J, Raja S, Davis MK, Tawfik O, Dey SK \& Das SK 2002 Evidence for coordinated interaction of cyclin D3 with p21 and cdk6 in directing the development of uterine stromal cell decidualization and polyploidy during implantation. Mechanisms of Development 111 99-113. (doi:10.1016/S0925-4773(01)00614-1)

Tan Y, Li M, Cox S, Davis MK, Tawfik O, Paria BC \& Das SK 2004 HB-EGF directs stromal cell polyploidy and decidualization via cyclin D3 during implantation. Developmental Biology 265 181-195. (doi:10.1016/j. ydbio.2003.09.019)

Tang B, Guller S \& Gurpide E 1993 Cyclic adenosine 3', 5'-monophosphate induces PRL expression in stromal cells isolated from human proliferative endometrium. Endocrinology 133 2197-2203. (doi:10.1210/en.133. 5.2197)

Tang B, Guller S \& Gurpide E 1994 Mechanism of human endometrial stromal cells decidualization. Annals of the New York Academy of Sciences 734 19-25. (doi:10.1111/j.1749-6632.1994.tb21731.x)

Taylor AH, Abbas MS, Habiba MA \& Konje JC 2010 Histomorphometric evaluation of cannabinoid receptor and anandamide modulating enzyme expression in the human endometrium through the menstrual cycle. Histochemistry and Cell Biology 133 557-565. (doi:10.1007/ s00418-010-0695-9)

Teklenburg G, Salker M, Molokhia M, Lavery S, Trew G, Aojanepong T, Mardon HJ, Lokugamage AU, Rai R, Landles C et al. 2010 Natural selection of human embryos: decidualizing endometrial stromal cells serve as sensors of embryo quality upon implantation. PLOS ONE $\mathbf{5}$ e10258. (doi:10.1371/journal.pone.0010258)

Weimar CH, Macklon NS, Post Uiterweer ED, Brosens JJ \& Gellersen B 2013 The motile and invasive capacity of human endometrial stromal cells: implications for normal and impaired reproductive function. Human Reproduction Update 19 542-557. (doi:10.1093/humupd/dmt025)

Received 1 April 2016

First decision 5 June 2016

Revised manuscript received 25 July 2016

Accepted 1 August 2016 